\title{
Hydrotalcite-derived Co-containing mixed metal oxide catalysts for methanol incineration
}

\author{
Role of cobalt content, $\mathrm{Mg} / \mathrm{Al}$ ratio and calcination temperature
}

\author{
Sylwia Basąg ${ }^{1}$ - František Kovanda ${ }^{2}$ Zofia Piwowarska1 • Andrzej Kowalczyk ${ }^{1}$ • \\ Katarzyna Pamin ${ }^{3} \cdot$ Lucjan Chmielarz $^{1}$
}

Received: 15 February 2017/ Accepted: 21 March 2017/Published online: 3 April 2017

(C) The Author(s) 2017. This article is an open access publication

\begin{abstract}
The $\mathrm{Co}-\mathrm{Mg}-\mathrm{Al}$ mixed metal oxides were prepared by calcination of co-precipitated hydrotalcite-like precursors at various temperatures $\left(600-800{ }^{\circ} \mathrm{C}\right)$, characterised with respect to chemical (AAS) and phase (XRD) composition, textural parameters (BET), form and aggregation of cobalt species (UV-vis-DRS) and their redox properties $\left(\mathrm{H}_{2}-\mathrm{TPR}\right.$, cyclic voltammetry). Moreover, the process of thermal decomposition of hydrotalcite-like materials to mixed metal oxide systems was studied by thermogravimetric method combined with the analysis of gaseous decomposition products by mass spectrometry. Calcined hydrotalcite-like materials were tested as catalysts for methanol incineration. Catalytic performance of the oxides depended on cobalt content, $\mathrm{Mg} / \mathrm{Al}$ ratio and calcination temperature. The catalysts with lower cobalt content, higher $\mathrm{Mg} / \mathrm{Al}$ ratio and calcined at lower temperatures $\left(600\right.$ or $\left.700{ }^{\circ} \mathrm{C}\right)$ were less effective in the process of methanol incineration. In a series of the studied catalysts, the best results, with respect to high catalytic activity and selectivity to $\mathrm{CO}_{2}$, were obtained for the mixed oxide with Co: $\mathrm{Mg}: \mathrm{Al}$ molar ratio of 10:57:33 calcined at $800{ }^{\circ} \mathrm{C}$. High activity of this catalyst was likely connected with the presence of a $\mathrm{Co}-\mathrm{Mg}-\mathrm{Al}$ spinel-type phases, containing
\end{abstract}

Lucjan Chmielarz

chmielar@chemia.uj.edu.pl

1 Faculty of Chemistry, Jagiellonian University, Ingardena 3, 30-060 Kraków, Poland

2 Department of Solid State Chemistry, University of Chemistry and Technology, Prague, Technická 5, 16628 Prague, Czech Republic

3 Jerzy Haber Institute of Catalysis and Surface Chemistry, Polish Academy of Sciences, Niezapominajek 8, Kraków, Poland easy reducible $\mathrm{Co}^{3+}$ cations, formed during high-temperature treatment of the hydrotalcite-like precursor.

Keywords Hydrotalcite-like materials · $\mathrm{Co}-\mathrm{Mg}-\mathrm{Al}$ mixed oxide catalysts - Spinel formation - VOC total oxidation . Methanol incineration

\section{Introduction}

Emissions of volatile organic compounds (VOCs) to the atmosphere from various sources are one of the most serious environmental problems [1]. Majority of VOCs is toxic and may take part in photochemical reactions in the atmosphere with other pollutants (e.g. nitrogen oxides) resulting in very dangerous secondary pollutants (e.g. ozone, aldehydes, peroxyacyl nitrates). The best way to reduce the VOCs emission is to eliminate them prior to their discharge. Among various methods employed for VOCs removal including thermal combustion, absorption, adsorptive recovery and biofiltration [2], the low-temperature catalytic incineration seems to be the most reliable and effective post-treatment technology [1]. The catalysts for VOCs incineration should effectively operate at relatively low temperatures to avoid additional heating of flue gases as well as to limit the formation of $\mathrm{NO}_{\mathrm{x}}$ by thermal mechanism [3]. Noble metals, such as Pt [4-7], Pd [8-10], $\mathrm{Rh}[11]$ and $\mathrm{Au}[12,13]$, belong to the most active and effective components of the catalysts for incineration of broad range of various VOCs. On the other hand, high cost of noble metals significantly limits commercial utilisation of such catalysts. Cobalt belongs to the most promising components of the non-noble metal-based catalytic systems for VOCs incineration. Solsona et al. [14] reported the supported and unsupported nanocrystalline cobalt oxides as 
very effective catalysts for propane incineration (total conversion of propane was achieved at about $250{ }^{\circ} \mathrm{C}$ ). The catalytic activity was mainly dependent on the crystallite size of cobalt oxides, decreasing with an increase in the crystallite size. The $\mathrm{Co}_{3} \mathrm{O}_{4}$ oxide was identified as the most catalytically active phase in the studied process. Jirátová et al. [15] studied total oxidation of toluene and ethanol over the hydrotalcite-derived $\mathrm{Co}-\mathrm{Mn}-\mathrm{Al}$ mixed oxide catalyst (Co:Mn:Al molar ratio of 4:1:1) modified with various amounts of potassium (0-3 mass \%). The Co$\mathrm{Mn}-\mathrm{Al}$ mixed oxide showed very good catalytic performance in the studied processes and addition of low amounts of potassium promoter additionally activated mixed metal oxide catalyst mainly by modification of the surface acid-base properties. Thus, it was shown that both the nanocrystalline structure of cobalt oxide phases as well as the surface acid-base properties of such catalytic systems are very important parameters that determine the catalytic performance in the processes of VOCs incineration. These observations were inspiration for the present study. Similarly to report of Jirátová et al. [15] mentioned above, the hydrotalcite-like materials were used as precursors of mixed metal oxide catalysts for VOCs incineration. Thermal treatment of such precursors results in nanocrystalline materials with homogenously distributed active components. By tailoring of chemical composition of hydrotalcite-like precursors and conditions of their thermal treatment, mixed metal oxide systems with various phase composition can be prepared [16-23]. The surface acid-base properties of hydrotalcite-derived mixed metal oxide catalysts can be controlled by changing of the $\mathrm{Mg} / \mathrm{Al}$ ratio in the hydrotalcite-like precursors.

The aim of the studies has been determination of the influence of the $\mathrm{Mg} / \mathrm{Al}$ ratio in the cobalt-containing hydrotalcite-like precursors as well as calcination conditions on their catalytic efficiency in the process of methanol incineration. Methanol was used as a model VOC molecule in the presented studies.

\section{Experimental}

\section{Samples preparation}

The hydrotalcite-like precursors with the intended $\mathrm{Co} / \mathrm{Mg} /$ Al molar ratios of 5/77/18, 10/72/18, 5/62/33 and 10/57/33 were synthesised by co-precipitation. The metal nitrates of p.a. purity, namely $\mathrm{Co}\left(\mathrm{NO}_{3}\right)_{2} \cdot 6 \mathrm{H}_{2} \mathrm{O}, \mathrm{Mg}\left(\mathrm{NO}_{3}\right)_{2} \cdot 6 \mathrm{H}_{2} \mathrm{O}$ and $\mathrm{Al}\left(\mathrm{NO}_{3}\right)_{3} \cdot 9 \mathrm{H}_{2} \mathrm{O}$ (all supplied by Sigma-Aldrich), $\mathrm{NaOH}$ (POCh), $\mathrm{Na}_{2} \mathrm{CO}_{3}$ (POCh) and distilled water were used for preparation of solutions. An aqueous solution $(450 \mathrm{~mL})$ of $\mathrm{Co}, \mathrm{Mg}$ and $\mathrm{Al}$ nitrates in appropriate molar ratio and total metal ions concentration of $1.0 \mathrm{~mol} \mathrm{~L}^{-1}$ was added with flow rate of $7.5 \mathrm{~mL} \mathrm{~min}^{-1}$ into $1000-\mathrm{mL}$ batch reactor containing $200 \mathrm{~mL}$ of distilled water. The flow rate of simultaneously added alkaline solution of $\mathrm{NaOH}$ (3.0 mol L $\left.{ }^{-1}\right)$ and $\mathrm{Na}_{2} \mathrm{CO}_{3}\left(0.5 \mathrm{~mol} \mathrm{~L}^{-1}\right)$ was controlled to maintain reaction $\mathrm{pH}$ of $10.0 \pm 0.2$. The co-precipitation was carried out at vigorous stirring at $60{ }^{\circ} \mathrm{C}$. The resulting suspension was stirred at $60{ }^{\circ} \mathrm{C}$ for $60 \mathrm{~min}$. The product was filtered off, washed thoroughly with distilled water and dried overnight at $60^{\circ} \mathrm{C}$ in air. Finally, the precursors were calcined at various temperatures $\left(600,700\right.$ or $\left.800{ }^{\circ} \mathrm{C}\right)$ for $9 \mathrm{~h}$ in air. The calcined samples were kept in a desiccator in order to avoid their contact with ambient atmosphere. The prepared mixed oxide samples were labelled by acronyms with molar ratios of cation constituents and calcination temperature (e.g. $\mathrm{Co}_{10} \mathrm{Mg}_{57} \mathrm{Al}_{33}-800$ ).

\section{Samples characterisation}

The cation composition of the prepared hydrotalcite-like precursors was determined by atomic absorption spectroscopy. The samples were dissolved in a hydrochloric acid solution (36\%), and the cation concentration in solutions was determined using 280FS AA instrument (Agilent Technologies) at the following wavelengths: Co $240.7 \mathrm{~nm}$, $\mathrm{Mg} 285.2 \mathrm{~nm}$ and $\mathrm{Al} 309.3 \mathrm{~nm}$.

The phase composition of the hydrotalcite-like precursors and related mixed metal oxides obtained by their calcination was determined by powder X-ray diffraction (XRD). The powder XRD patterns were recorded with a D2 Phaser diffractometer (Bruker) using Co $\mathrm{K}_{\alpha 1}$ radiation $(\lambda=0.179 \mathrm{~nm})$ in the $2 \Theta$ range from $8^{\circ}$ to $80^{\circ}$, step size $0.02^{\circ}$. The qualitative analysis was performed with a HighScore Plus 4.0 software package (PANanalytical). The hydrotalcite lattice parameters $a$ and $c$ were determined from XRD data using the following formulas: $a=2 d_{110}$ and $c=\left(3 d_{003}+6 d_{006}\right) / 2$. The mean coherence length $L$ was calculated from the FWHM values (broadening at half of the maximum intensity) of the diffraction lines using Scherrer equation.

Thermal decomposition of the hydrotalcite-like precursors was studied by thermogravimetric method coupled with QMS analysis of evolved gases. The TG-DTG-QMS measurements were carried out using a Mettler Toledo $851^{\mathrm{e}}$ instrument operated under a flow of air $\left(80 \mathrm{~mL} \mathrm{~min}^{-1}\right)$ in the temperature range of $25-1000{ }^{\circ} \mathrm{C}$ with a heating rate of $10^{\circ} \mathrm{C} \mathrm{min}^{-1}$. The gases evolved during the thermal decomposition of the samples were continuously monitored by quadrupole mass spectrometer ThermoStar (Balzers) connected directly to microbalance for the chosen mass numbers $\mathrm{m} / \mathrm{z}\left(18-\mathrm{H}_{2} \mathrm{O}^{+}, 30-\mathrm{NO}^{+}\right.$and 44- $\mathrm{CO}_{2}^{+}$).

The specific surface area of the calcined samples was determined by the BET method using a 3Flex 
(Micromeritics) automated gas adsorption system. Prior to the nitrogen adsorption at $-196{ }^{\circ} \mathrm{C}$ all the samples were outgassed under vacuum at $350^{\circ} \mathrm{C}$ for $24 \mathrm{~h}$.

The UV-vis-DR spectra of the calcined samples were recorded using an Evolution 600 (Thermo) spectrophotometer. The measurements were performed in the range from 190 to $900 \mathrm{~nm}$ with a resolution of $2 \mathrm{~nm}$.

Cyclic voltammograms of the calcined samples were recorded in a three-electrode cell using a graphite paste electrode as the working electrode, platinum coil as the auxiliary electrode and $\mathrm{Ag} \mid \mathrm{AgCl}$ as the reference electrode. Composite paste was prepared by mixing synthetic graphite $(100-150 \mathrm{mg})$ with Nujol $(0.05 \mathrm{~mL})$ and a small amount of the mixed oxide catalyst $(0.005-0.010 \mathrm{~g})$. The measurements were performed in acetate buffer $(\mathrm{pH}=4.6)$ as electrolyte at a scan rate of $50 \mathrm{mV} \mathrm{s}^{-1}$. Before experiment, the solutions were pretreated with argon to keep oxygen-free atmosphere during the measurement.

The reducibility of the calcined samples was studied by temperature-programmed reduction method $\left(\mathrm{H}_{2}-\mathrm{TPR}\right)$. Experiments were carried out in a fixed-bed flow microreactor starting from room temperature to $950{ }^{\circ} \mathrm{C}$, with a linear heating rate of $10^{\circ} \mathrm{C} \mathrm{min}{ }^{-1} \cdot \mathrm{H}_{2}$-TPR runs were carried out in a flow $\left(10 \mathrm{~mL} \mathrm{~min}^{-1}\right)$ of 5 vol. $\% \mathrm{H}_{2}$ diluted in $\mathrm{Ar}$ (N5 quality, Messer). The evolution of hydrogen was detected by microvolume TCD (Valco).

\section{Catalytic studies}

The mixed oxide samples obtained from hydrotalcite-like precursors at 600,700 and $800{ }^{\circ} \mathrm{C}$ were tested as catalysts for methanol incineration. Catalytic experiments were performed in a fixed-bed flow quartz microreactor system under atmospheric pressure in the temperature range from 125 to $425{ }^{\circ} \mathrm{C}$ with an isothermal steps every $25^{\circ} \mathrm{C}$. For each test, $100 \mathrm{mg}$ of catalyst was outgassed in a flow of air at $500{ }^{\circ} \mathrm{C}$ for $30 \mathrm{~min}$. After cooling down to $125{ }^{\circ} \mathrm{C}$, the gas mixture containing $3.7 \mathrm{vol} \%$ of methanol diluted in air (total flow rate of $20 \mathrm{~mL} \mathrm{~min}{ }^{-1}$ ) was supplied into the reactor by the isothermal saturator $\left(0{ }^{\circ} \mathrm{C}\right)$. The reaction products were analysed using a gas chromatograph SRI 8610C equipped with Hayesep D column as well as methaniser-FID detection system.

\section{Results and discussion}

Formation of hydrotalcite-like materials after co-precipitation reaction was proven by powder XRD results. In the XRD patterns of the co-precipitated precursors (Fig. 1), only diffraction lines characteristic for hydrotalcite-like compounds were found, no other crystalline phase was

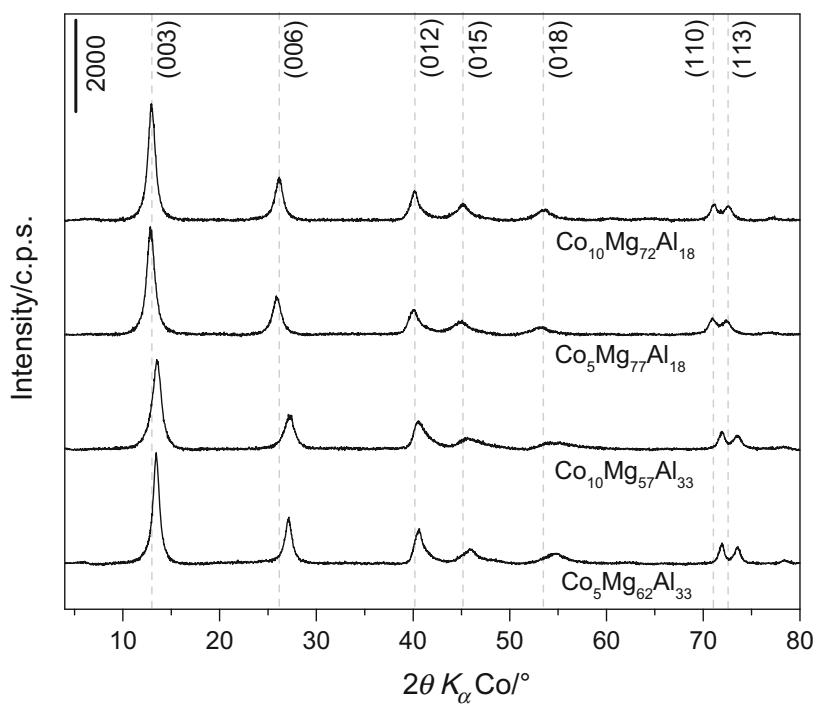

Fig. 1 Powder XRD patterns of the co-precipitated hydrotalcite-like precursors

detected. The hydrotalcite lattice parameters $a$ and $c$, determined from XRD analysis, are compared in Table 1. Slightly smaller $a$ parameter observed for the samples with increased aluminium content can be explained by smaller ionic radius of $\mathrm{Al}^{3+}(53 \mathrm{pm})$ in comparison with radius of $\mathrm{Mg}^{2+}(72 \mathrm{pm})$. The samples with increased aluminium loading in the hydrotalcite-like samples exhibited also slightly smaller $d_{003}$ basal spacing, which resulted in a decreased $c$ parameter. Similar effect was observed by authors for the $\mathrm{Cu}-\mathrm{Mg}-\mathrm{Al}$ hydrotalcite-like materials [16]. This effect could be related to the increased $\mathrm{Al}^{3+}$ content in the brucite-like layers, which causes the higher net positive charge and tighter arrangement of the layers due to stronger electrostatic interactions between the layers and interlayer anions. The mean coherence length evaluated from XRD data is related to structure ordering; it was evaluated from broadening of hydrotalcite (hkl 003, 006, 110) diffraction line using Scherrer equation; the $L$ values varied in the range of 9.1-12.8 nm and confirmed formation of wellcrystalline product.

Cation composition of prepared hydrotalcite-like precursors was determined by AAS after samples dissolution in hydrochloric acid. The results presented in Table 2 show

Table 1 Lattice parameters and mean coherence length L (calculated from FWHM of (003), (006), (110) line) of co-precipitated hydrotalcite-like precursors

\begin{tabular}{lllr}
\hline Sample & Parameter $a / \mathrm{nm}$ & Parameter $c / \mathrm{nm}$ & $L / \mathrm{nm}$ \\
\hline $\mathrm{Co}_{5} \mathrm{Mg}_{62} \mathrm{Al}_{33}$ & 0.305 & 2.297 & 12.8 \\
$\mathrm{Co}_{10} \mathrm{Mg}_{57} \mathrm{Al}_{33}$ & 0.305 & 2.287 & 9.4 \\
$\mathrm{Co}_{5} \mathrm{Mg}_{77} \mathrm{Al}_{18}$ & 0.308 & 2.395 & 9.1 \\
$\mathrm{Co}_{10} \mathrm{Mg}_{72} \mathrm{Al}_{18}$ & 0.307 & 2.370 & 9.9 \\
\hline
\end{tabular}


that molar ratios of cations calculated from the measured data are very close to the intended values, i.e. the molar ratios of cations adjusted in nitrate solutions used in coprecipitation reaction.

The process of thermal decomposition of the hydrotalcite-like samples into mixed oxides was studied by thermogravimetry coupled with analysis of gaseous products released during thermal treatment of the samples (TG-QMS). Results of thermal analysis are presented in Fig. 2. In general, thermal behaviour of hydrotalcite-like compounds may be characterised by two main transitions: (1) the loss of interlayer water without collapse of the layered hydrotalcite structure and (2) subsequent loss of hydroxyl groups accompanied by water release from the brucite-like layers and decomposition of volatile interlayer anions (e.g. carbonate or nitrate) at higher temperatures [24]. The temperature ranges of these two transitions depend on cationic composition of the hydroxide layers and interlayer anions. The first transition related to the loss of interlayer water is represented by DTG peaks and maxima of water evolution at temperatures below $250{ }^{\circ} \mathrm{C}$. It should be noted that in the case of the samples with higher $\mathrm{Al} / \mathrm{Mg}$ ratio $\left(\mathrm{Co}_{5} \mathrm{Mg}_{62} \mathrm{Al}_{33}\right.$ and $\left.\mathrm{Co}_{10} \mathrm{Mg}_{57} \mathrm{Al}_{33}\right)$ these peaks were detected at temperatures of about $20-25{ }^{\circ} \mathrm{C}$ higher than in the samples with the lower $\mathrm{Al} / \mathrm{Mg}$ ratio $\left(\mathrm{Co}_{5} \mathrm{Mg}_{77} \mathrm{Al}_{18}\right.$ and $\left.\mathrm{Co}_{10} \mathrm{Mg}_{72} \mathrm{Al}_{18}\right)$. It could be explained by more effective stabilisation of interlayer water in the samples with the increased content of aluminium. Apart from interlayer water, very small amounts of carbon dioxide were also released at temperatures below $250{ }^{\circ} \mathrm{C}$, likely as a result of $\mathrm{CO}_{2}$ desorption from the samples surface or thermal decomposition of unstable surface carbonates.

The second stage of the hydrotalcite-like samples decomposition, including dehydroxylation of the brucitelike layers as well as decomposition of interlayer anions, was represented by DTG peaks and maxima of $\mathrm{H}_{2} \mathrm{O}, \mathrm{CO}_{2}$ and NO evolution observed above $250{ }^{\circ} \mathrm{C}$. Release of $\mathrm{CO}_{2}$ and $\mathrm{H}_{2} \mathrm{O}$ from the samples with the lower $\mathrm{Al} / \mathrm{Mg}$ ratio $\left(\mathrm{Co}_{5} \mathrm{Mg}_{77} \mathrm{Al}_{18}\right.$ and $\left.\mathrm{Co}_{10} \mathrm{Mg}_{72} \mathrm{Al}_{18}\right)$ was represented by single sharp maxima at about $355-375{ }^{\circ} \mathrm{C}$ (Fig. 2). For

Table 2 Cation composition of the samples

\begin{tabular}{lccl}
\hline Sample & \multicolumn{3}{l}{ Content of cations $/ \mathrm{mol} \%$} \\
\cline { 2 - 4 } & $\mathrm{Co}$ & $\mathrm{Mg}$ & $\mathrm{Al}$ \\
\hline $\mathrm{Co}_{5} \mathrm{Mg}_{62} \mathrm{Al}_{33}$ & 5.1 & 61.8 & 33.1 \\
$\mathrm{Co}_{10} \mathrm{Mg}_{57} \mathrm{Al}_{33}$ & 9.8 & 57.1 & 33.1 \\
$\mathrm{Co}_{5} \mathrm{Mg}_{77} \mathrm{Al}_{18}$ & 5.0 & 72.3 & 22.7 \\
$\mathrm{Co}_{10} \mathrm{Mg}_{72} \mathrm{Al}_{18}$ & 10.1 & 71.2 & 18.7 \\
\hline
\end{tabular}

the samples with the higher $\mathrm{Al} / \mathrm{Mg}$ ratio $\left(\mathrm{Co}_{5} \mathrm{Mg}_{62} \mathrm{Al}_{33}\right.$ and $\mathrm{Co}_{10} \mathrm{Mg}_{57} \mathrm{Al}_{33}$ ), the profiles of $\mathrm{H}_{2} \mathrm{O}$ and $\mathrm{CO}_{2}$ evolution were more complex and consisted of at least two overlapping peaks of water release and at least three peaks of carbon dioxide evolution. The low-temperature peak of $\mathrm{H}_{2} \mathrm{O}$ release was located at about $310^{\circ} \mathrm{C}$, while the hightemperature peaks were located at 380 and $360{ }^{\circ} \mathrm{C}$ for the $\mathrm{Co}_{5} \mathrm{Mg}_{62} \mathrm{Al}_{33}$ and $\mathrm{Co}_{10} \mathrm{Mg}_{57} \mathrm{Al}_{33}$ samples, respectively. Comparing positions of these peaks with temperatures of pure $\mathrm{Al}(\mathrm{OH})_{3}$ and $\mathrm{Mg}(\mathrm{OH})_{2}$ dehydroxylation, which was determined to be $295{ }^{\circ} \mathrm{C}$ [25] and $377^{\circ} \mathrm{C}$ [26], respectively, it could be suggested that the low-temperature peak was likely related to the release of $\mathrm{OH}^{-}$anions attached to $\mathrm{Al}^{3+}$, while the high-temperature peak to dehydroxylation of $\mathrm{OH}^{-}$attached to $\mathrm{Mg}^{2+}$ cations. Such splitting of the water evolution process was not observed for $\mathrm{Co}_{5} \mathrm{Mg}_{77} \mathrm{Al}_{18}$ and $\mathrm{Co}_{10} \mathrm{Mg}_{72} \mathrm{Al}_{18}$ precursors due to lower content of aluminium in these samples; however, the asymmetry and positions of the water release peaks may suggest that it is a superposition of the peaks related to dehydroxylation of $\mathrm{OH}^{-}$bounded to $\mathrm{Mg}^{2+}$ with the smaller contribution of $\mathrm{OH}^{-}$attached to $\mathrm{Al}^{3+}$. The profiles of $\mathrm{CO}_{2}$ evolution from $\mathrm{Co}_{5} \mathrm{Mg}_{62} \mathrm{Al}_{33}$ and $\mathrm{Co}_{10}$ $\mathrm{Mg}_{57} \mathrm{Al}_{33}$ were also much more complex comparing to that observed for the $\mathrm{Co}_{5} \mathrm{Mg}_{77} \mathrm{Al}_{18}$ and $\mathrm{Co}_{10} \mathrm{Mg}_{72} \mathrm{Al}_{18}$ samples and consisted of at least four peaks. As it was mentioned above, small peaks located below $250{ }^{\circ} \mathrm{C}$ were possibly related to $\mathrm{CO}_{2}$ desorption from the samples surface or thermal decomposition of unstable surface carbonates. Peaks centred at about 310 and $395-400{ }^{\circ} \mathrm{C}$ were assigned to decomposition of interlayer carbonates and indicated the presence of $\mathrm{CO}_{3}{ }^{2-}$ anions stabilised in the interlayer with various strengths. It could be explained by different interaction and therefore also stabilisation of interlayer anions by $\mathrm{Al}^{3+}$ and $\mathrm{Mg}^{2+}$ cations in hydroxide layers. Moreover, $\mathrm{CO}_{2}$ release related to decomposition of very stable carbonates was detected at temperature of about $605-610^{\circ} \mathrm{C}$. Similar effect was reported in our previous studies for the $\mathrm{Cu}_{5} \mathrm{Mg}_{66} \mathrm{Al}_{29}$ and $\mathrm{Mg}_{71} \mathrm{Al}_{29}$ hydrotalcite-like samples, which released small amounts of $\mathrm{CO}_{2}$ at temperatures as high as 637 and $588{ }^{\circ} \mathrm{C}$, respectively [27]. In the case of the samples with the lower $\mathrm{Al} / \mathrm{Mg}$ ratio, only one peak related to the thermal decomposition of interlayer carbonates, centred at about 365 and $375{ }^{\circ} \mathrm{C}$, was detected for $\mathrm{Co}_{5} \mathrm{Mg}_{77} \mathrm{Al}_{18}$ and $\mathrm{Co}_{10} \mathrm{Mg}_{72} \mathrm{Al}_{18}$, respectively. Release of small amounts of NO was observed only for the samples with the lower Al/ $\mathrm{Mg}$ ratio and was represented by peaks located at about 355 and $470{ }^{\circ} \mathrm{C}$ in the $\mathrm{NO}$ evolution profile of $\mathrm{Co}_{5}$ $\mathrm{Mg}_{77} \mathrm{Al}_{18}$ and maximum of $\mathrm{NO}$ evolution at about $500{ }^{\circ} \mathrm{C}$ for the $\mathrm{Co}_{10} \mathrm{Mg}_{72} \mathrm{Al}_{18}$ sample. These results may indicate the presence of a small amount of nitrate anions in the interlayer of the $\mathrm{Co}_{5} \mathrm{Mg}_{77} \mathrm{Al}_{18}$ and $\mathrm{Co}_{10} \mathrm{Mg}_{72} \mathrm{Al}_{18}$ samples, 

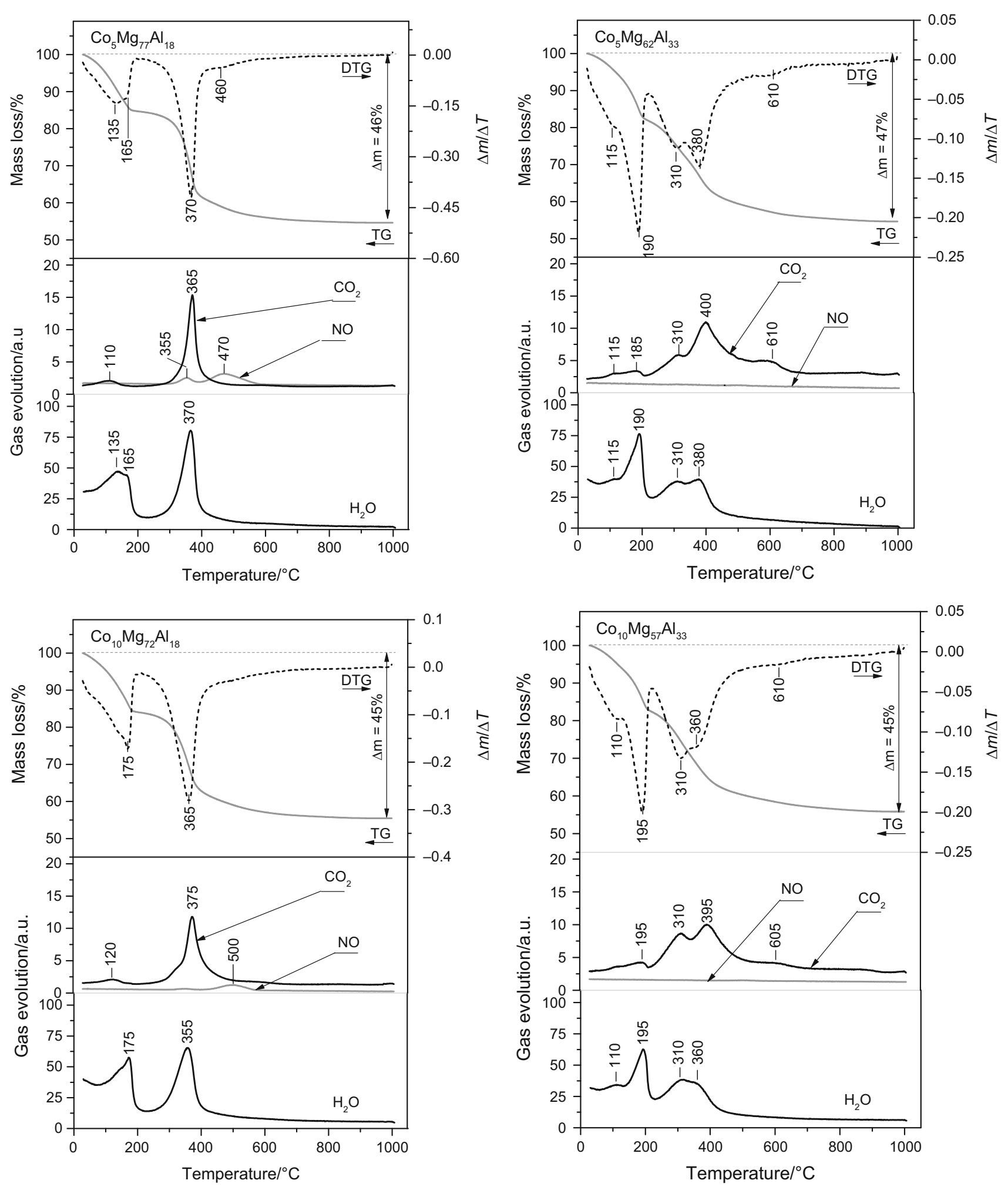

Fig. 2 Results of thermogravimetry coupled with evolved gas analysis documenting thermal decomposition of the co-precipitated hydrotalcitelike precursors

but the NO evolution was more likely connected with decomposition of residual nitrates, which were not removed from the samples surface after washing.
Based on the results of thermogravimetric analysis, temperatures of $600{ }^{\circ} \mathrm{C}$ and higher were chosen for calcination of the prepared hydrotalcite-like precursors. Such 
temperatures should ensure a complete decomposition of the hydrotalcite-like precursors and their transformation into mixed metal oxides. The variation of calcination temperatures should result in the preparation of the samples with various phase composition, crystallinity and textural properties.

Powder XRD patterns of the calcined samples are presented in Fig. 3. The diffraction lines characteristic for $\mathrm{MgO}$ (periclase) were found in the powder XRD patterns of the mixed oxides obtained at 600 and $700{ }^{\circ} \mathrm{C}$ (the lines at approximately $43^{\circ}, 50^{\circ}$ and $74^{\circ} 2 \theta$ ). Phases with spinel structure (represented by diffraction lines at about $22^{\circ}, 36^{\circ}, 52^{\circ}, 70^{\circ}$ and $77^{\circ} 2 \theta$ ) were identified, together with periclase-like oxides, in the powder XRD patterns of the samples with the higher $\mathrm{Al} / \mathrm{Mg}$ ratio $\left(\mathrm{Co}_{5} \mathrm{Mg}_{62} \mathrm{Al}_{33}\right.$ and $\left.\mathrm{Co}_{10} \mathrm{Mg}_{57} \mathrm{Al}_{33}\right)$ calcined at $800{ }^{\circ} \mathrm{C}$. The spinel diffraction lines were not found in the samples with the lower $\mathrm{Al} / \mathrm{Mg}$ ratio $\left(\mathrm{Co}_{5} \mathrm{Mg}_{77} \mathrm{Al}_{18}\right.$ and $\left.\mathrm{Co}_{10} \mathrm{Mg}_{72} \mathrm{Al}_{18}\right)$. Comparing the powder XRD patterns of the samples with the higher $\mathrm{Al} / \mathrm{Mg}$ ratio $\left(\mathrm{Co}_{5} \mathrm{Mg}_{62} \mathrm{Al}_{33}\right.$ and $\left.\mathrm{Co}_{10} \mathrm{Mg}_{57} \mathrm{Al}_{33}\right)$ calcined at 600 and $800{ }^{\circ} \mathrm{C}$, the positions of periclase diffraction lines were shifted from $50.8^{\circ}$ to $50.2^{\circ}$ and $74.4^{\circ}$ to $73.7^{\circ}$, respectively. The corresponding slight increase in periclase lattice parameter from about 0.4211 to $0.4225 \mathrm{~nm}$ could be explained by incorporation of $\mathrm{Al}^{3+}$ cations into $\mathrm{MgO}$ lattice in the early stages of mixed oxide formation after thermal decomposition of the hydrotalcite-like precursors. Increasing calcination temperature enhanced crystallisation of the MgO-like phase and formation of $\mathrm{Mg}-\mathrm{Al}$ spinel-type phase. The lattice parameter of MgO-like phase formed at $800^{\circ}(0.4225 \mathrm{~nm})$ is close to that reported for reference $\mathrm{MgO}(0.4223 \mathrm{~nm}$, PDF No. 04-012-6481). Analogous changes in lattice parameters of NiO-like phase were observed during calcination of $\mathrm{Ni}-\mathrm{Al}$ layered double hydroxides [28]. For the samples with the lower $\mathrm{Al} / \mathrm{Mg}$ ratio $\left(\mathrm{Co}_{5} \mathrm{Mg}_{77} \mathrm{Al}_{18}\right.$ and $\mathrm{Co}_{10}$ $\mathrm{Mg}_{72} \mathrm{Al}_{18}$ ), only negligible shift (below $0.2^{\circ}$ ) in the positions of periclase diffraction lines was detected. Moreover, cobalt cations (both $\mathrm{Co}^{2+}$ and even $\mathrm{Co}^{3+}$ ) were very likely incorporated into the lattice of periclase-like and spinel-type oxides. Radius of cobalt cations is larger than that of $\mathrm{Al}^{3+}$ ones and not very different from the radius of $\mathrm{Mg}^{2+}$ cations; therefore, incorporation of small amounts of cobalt cations into the lattice of $\mathrm{Mg}-\mathrm{Al}$ mixed oxides is practically impossible to detect by XRD.

The measured BET surface areas of the mixed oxide samples obtained at various temperatures are compared in Table 3. The results lead to the following conclusions: (1) the increase in cobalt content in the samples decreased the BET surface area; (2) the samples with higher $\mathrm{Al} / \mathrm{Mg}$
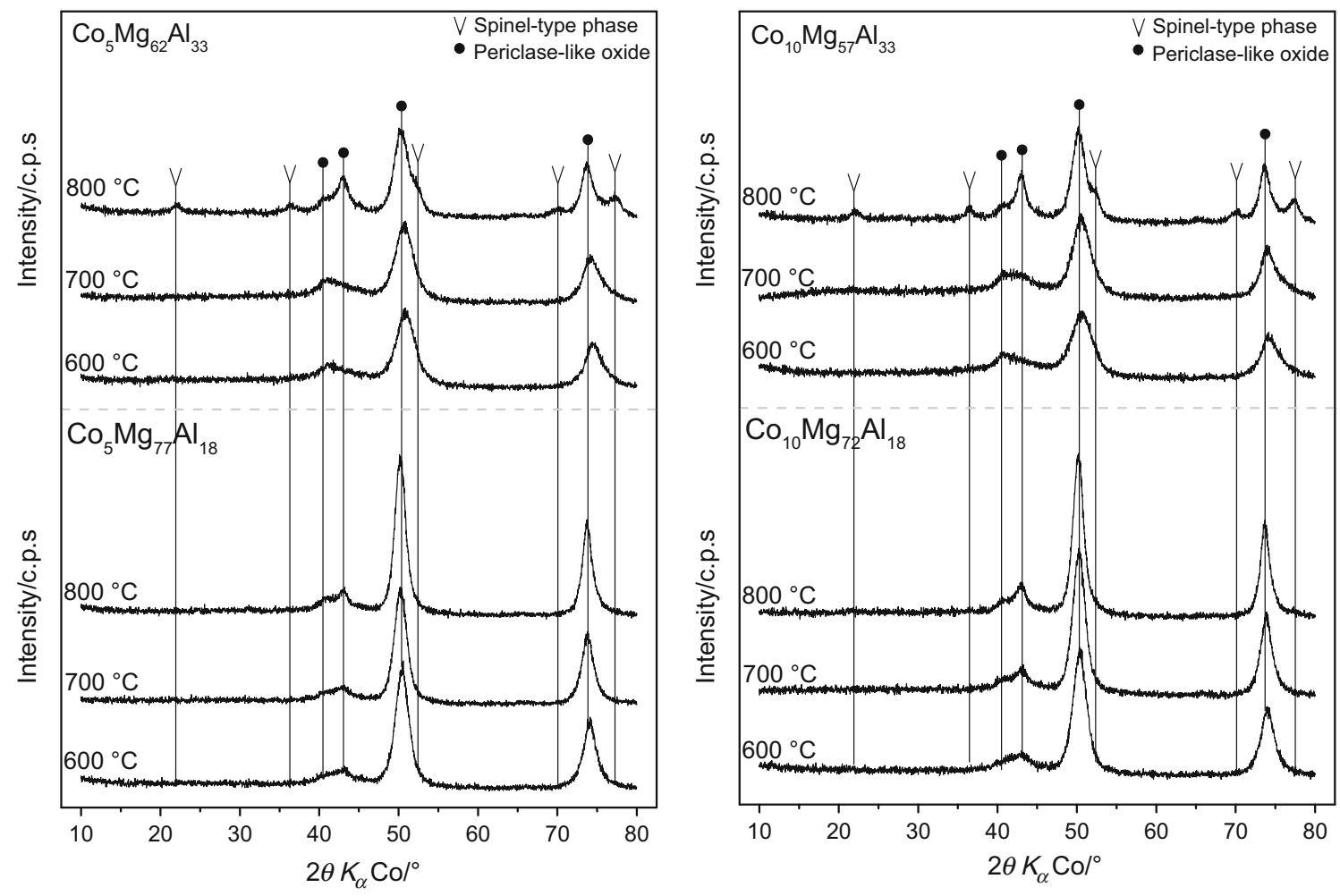

Fig. 3 Powder XRD patterns of the mixed oxides obtained at various temperatures from the hydrotalcite-like precursors 
Table 3 BET surface area of the samples calcined at various temperatures

\begin{tabular}{llll}
\hline Sample & \multicolumn{3}{l}{ BET specific surface area $/ \mathrm{m}^{2} \mathrm{~g}^{-1}$} \\
\cline { 2 - 4 } & $600{ }^{\circ} \mathrm{C}$ & $700{ }^{\circ} \mathrm{C}$ & $800{ }^{\circ} \mathrm{C}$ \\
\hline $\mathrm{Co}_{5} \mathrm{Mg}_{62} \mathrm{Al}_{33}$ & 257 & 244 & 211 \\
$\mathrm{Co}_{10} \mathrm{Mg}_{57} \mathrm{Al}_{33}$ & 238 & 226 & 176 \\
$\mathrm{Co}_{5} \mathrm{Mg}_{77} \mathrm{Al}_{18}$ & 250 & 221 & 209 \\
$\mathrm{Co}_{10} \mathrm{Mg}_{72} \mathrm{Al}_{18}$ & 235 & 220 & 176 \\
\hline
\end{tabular}

ratio showed larger surface area and (3) the increase in calcination temperatures resulted in gradual decrease in the surface area of the samples.

The cobalt species formed during calcination of hydrotalcite-like precursors were analysed by UV-vis-DR spectroscopy (Fig. 4). The spectra consisted of the bands in two regions characteristic of $\mathrm{Co}^{2+}$ cations below $330 \mathrm{~nm}$ and in the range $500-700 \mathrm{~nm}$, as well as in the region characteristic of $\mathrm{Co}^{3+}$ cations in the range $330-480 \mathrm{~nm}$ [29]. The bands in the UV region below $330 \mathrm{~nm}$ were assigned to a low-energy charge transfer between the oxygen ligands and central $\mathrm{Co}^{2+}$ ion in tetrahedral symmetry [30]. The absorption bands, centred at $360 \mathrm{~nm}$, were assigned to the ${ }^{1} \mathrm{~A}_{1 \mathrm{~g}} \rightarrow{ }^{1} \mathrm{~T}_{2 \mathrm{~g}}$ transition in $\mathrm{Co}^{3+}$ ions in octahedral [31, 32]. The bands mentioned above were present in the spectra of all the studied samples and

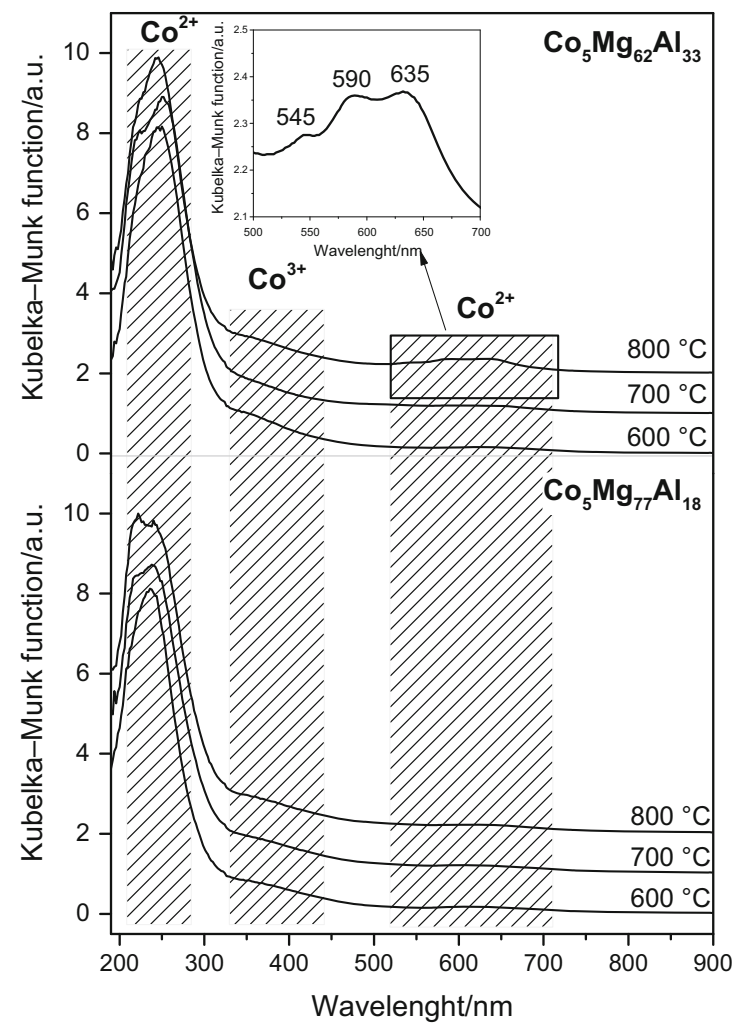

indicated that major part of cobalt cations was present in the form of $\mathrm{Co}^{2+}$; a part of cobalt cations was oxidised during calcination in air to $\mathrm{Co}^{3+}$ species. Calcination of the samples at high temperature of $800{ }^{\circ} \mathrm{C}$, especially in the case of the samples with the higher $\mathrm{Al} / \mathrm{Mg}$ ratio $\left(\mathrm{Co}_{5}\right.$ $\mathrm{Mg}_{62} \mathrm{Al}_{33}$ and $\mathrm{Co}_{10} \mathrm{Mg}_{57} \mathrm{Al}_{33}$ ), resulted in the appearance of the well-defined triplet at 545, 590 and $635 \mathrm{~nm}$ (inserts in Fig. 4) corresponding to ${ }^{4} \mathrm{~A}_{2} \rightarrow{ }^{4} \mathrm{~T}_{1}$ (P) transition in $\mathrm{Co}^{2+}$ ions in tetrahedral environment, characteristic for $\mathrm{CoAl}_{2} \mathrm{O}_{4}$ spinel [33]. The formation of such spinel was reported to occur during thermal treatment of the samples containing small amounts of uniformly distributed cobalt species [34]. On the other hand, the band characteristic of $\mathrm{Co}^{3+}$ cations in the range $330-480 \mathrm{~nm}$ could indicate the presence of spinel phases containing trivalent cobalt, e.g. $\mathrm{MgCo}_{2} \mathrm{O}_{4}, \mathrm{MgCoAlO}_{4}$ and $\mathrm{Co}_{3} \mathrm{O}_{4}$. However, the absence of the band at about $690-700 \mathrm{~nm}$ corresponding to ${ }^{1} \mathrm{~A}_{1 \mathrm{~g}} \rightarrow{ }^{1} \mathrm{~T}_{1 \mathrm{~g}}$ transition in $\mathrm{Co}^{3+}$ ions in the octahedral coordination implied that $\mathrm{Co}_{3} \mathrm{O}_{4}$ spinel was not formed or was formed only in a very small amounts during calcination of the hydrotalcite-like precursors [34]. Moreover, it should be noted that the highest intensity of the band characteristic of $\mathrm{Co}^{3+}$ cations (330-480 nm) was observed for the samples with the higher cobalt content and lower $\mathrm{Al} / \mathrm{Mg}$ ratio $\left(\mathrm{Co}_{5} \mathrm{Mg}_{77} \mathrm{Al}_{18}\right.$ series). Therefore, it seems possible that this band represents mainly $\mathrm{MgCo}_{2} \mathrm{O}_{4}$ with the inverse spinel structure [35].

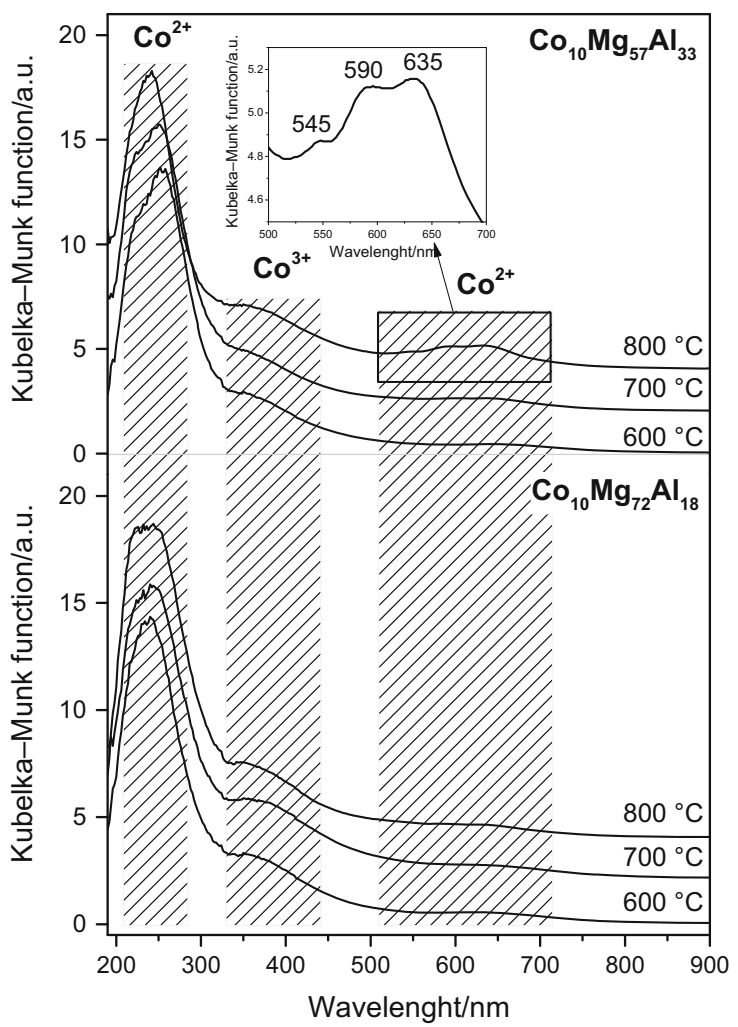

Fig. 4 UV-vis-DR spectra of the mixed oxides obtained at various temperatures from the hydrotalcite-like precursors 
The electrochemical properties of the mixed oxide samples prepared at various temperatures were examined by cyclic voltammetry. Figure 5 shows the cyclic voltammograms obtained for the $\mathrm{Co}_{10} \mathrm{Mg}_{57} \mathrm{Al}_{33}$ sample calcined at 600 and $800{ }^{\circ} \mathrm{C}$. The oxidation wave for the sample calcined at $600{ }^{\circ} \mathrm{C}$ is visible at Epa $=301 \mathrm{mV}$ and reduction wave can be observed at Epc $=8 \mathrm{mV}$. The shape of the voltammogram profiles shows that the redox process is irreversible and oxidation dominates over reduction in the mixed oxide catalyst. In the $\mathrm{Co}_{10} \mathrm{Mg}_{57} \mathrm{Al}_{33}$ sample calcined at $800{ }^{\circ} \mathrm{C}$, the oxidation wave is present at $\mathrm{Epa}=301 \mathrm{mV}$, so exactly at the same position as for the catalyst prepared at $600{ }^{\circ} \mathrm{C}$. On the other hand, significant differences are observed in the reduction waves of the $\mathrm{Co}_{10} \mathrm{Mg}_{57} \mathrm{Al}_{33}$ sample calcined at 600 and $800{ }^{\circ} \mathrm{C}$. In the catalyst calcined at higher temperature, the reduction wave was shifted to $21 \mathrm{mV}$ and, moreover, additional low-intensive reduction wave appeared at about $121 \mathrm{mV}$. Such result may indicate that increase in calcination temperature from 600 to $800{ }^{\circ} \mathrm{C}$ generated more easily reducible cobalt species in the $\mathrm{Co}_{10} \mathrm{Mg}_{57} \mathrm{Al}_{33}$ sample.

Figure 6 presents the results of the multicycle voltammetry performed for the $\mathrm{Co}_{10} \mathrm{Mg}_{57} \mathrm{Al}_{33}$ sample calcined at $800{ }^{\circ} \mathrm{C}$. In the initial cycles, splitting of the oxidation wave for two components was observed. This effect was less significant in the subsequent redox cycles, and finally an increase in the anodic current and the formation of one intensive oxidation wave occurred. As it was mentioned above, two reduction waves were observed in the profile of the $\mathrm{Co}_{10} \mathrm{Mg}_{57} \mathrm{Al}_{33}$ sample calcined at $800{ }^{\circ} \mathrm{C}$. In the subsequent redox cycles, the intensity of these waves,

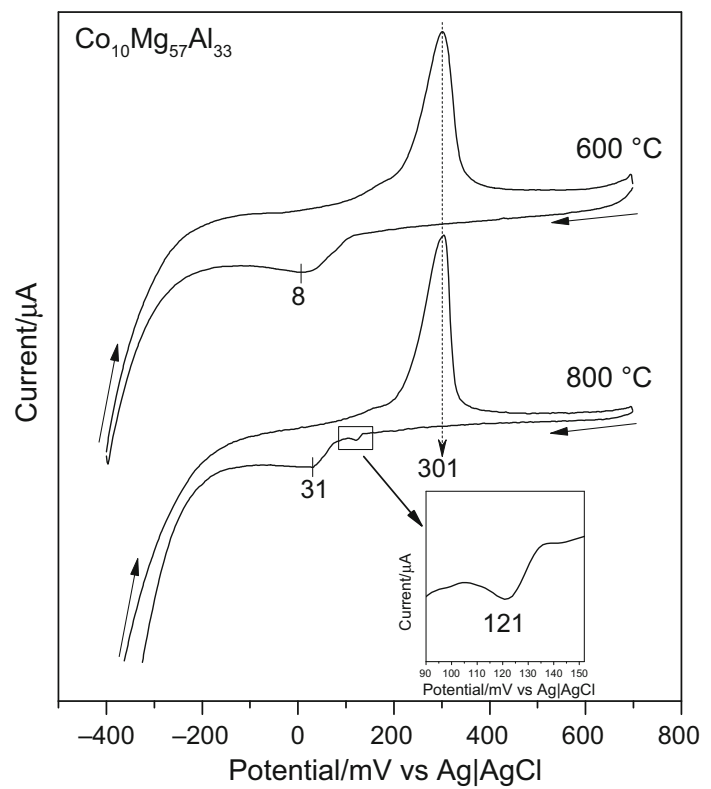

Fig. 5 Results of cyclic voltammetry measurements obtained for $\mathrm{Co}_{10} \mathrm{Mg}_{57} \mathrm{Al}_{33}$ mixed oxides obtained at 600 and $800{ }^{\circ} \mathrm{C}$

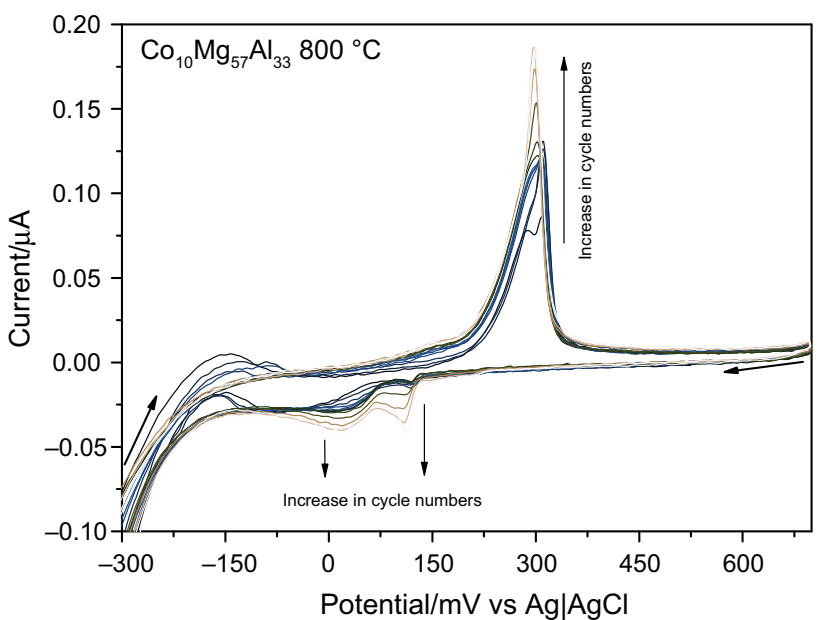

Fig. 6 Results of multicycle voltammetry measurements performed for the $\mathrm{Co}_{10} \mathrm{Mg}_{57} \mathrm{Al}_{33}$ mixed oxide sample obtained at $800{ }^{\circ} \mathrm{C}$

especially that at higher positive potential, gradually increased. It could be explained by the formation of the more easily reducible cobalt species in the subsequent redox cycles. Such effects were not observed for the $\mathrm{Co}_{10} \mathrm{Mg}_{57} \mathrm{Al}_{33}$ sample calcined at $600{ }^{\circ} \mathrm{C}$, for which no changes in the subsequent oxidation and reduction wave profiles were found.

Figure 7 presents the results of temperature-programmed reduction $\left(\mathrm{H}_{2}\right.$-TPR) obtained for the $\mathrm{Co}_{10} \mathrm{Mg}_{57}$ $\mathrm{Al}_{33}$ sample calcined at 600 and $800{ }^{\circ} \mathrm{C}$. The reduction in cobalt species proceeded in two steps. In the first step, $\mathrm{Co}^{3+}$ was reduced to $\mathrm{Co}^{2+}$, while in the second step $\mathrm{Co}^{2+}$ to $\mathrm{Co}^{0}[36,37]$. It should be noted that in the case of the sample calcined at $800{ }^{\circ} \mathrm{C}$ the reduction of $\mathrm{Co}^{3+}$ to $\mathrm{Co}^{2+}$ took place at temperature lower by about $80{ }^{\circ} \mathrm{C}$ in comparison with the sample calcined at $600{ }^{\circ} \mathrm{C}$. Thus, the

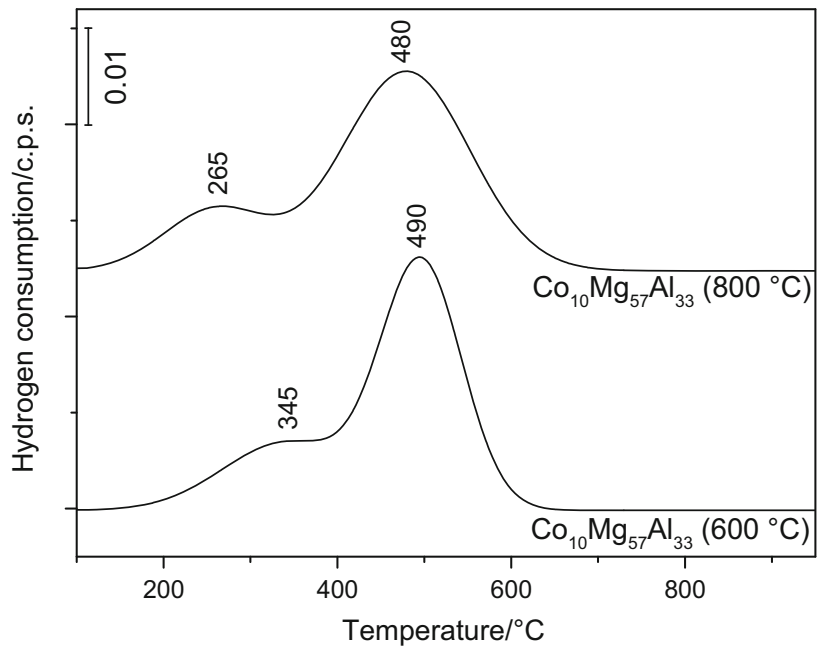

Fig. 7 Results of temperature-programmed reduction $\left(\mathrm{H}_{2}-\mathrm{TPR}\right)$ performed for the $\mathrm{Co}_{10} \mathrm{Mg}_{57} \mathrm{Al}_{33}$ mixed oxide sample obtained at 600 and $800{ }^{\circ} \mathrm{C}$ 
results of these studies are fully consistent with the results of the cyclic voltammetry and support hypothesis that calcination of $\mathrm{Co}_{10} \mathrm{Mg}_{57} \mathrm{Al}_{33}$ at $800{ }^{\circ} \mathrm{C}$ generated cobalt species containing easy reducible $\mathrm{Co}^{3+}$.

Mixed oxides obtained from hydrotalcite-like precursors at various temperatures were tested as catalysts for incineration of methanol, which was used as a model VOC. It can be seen from Fig. 8 that catalytic performance of the studied samples depended on chemical composition as well as calcination temperature. In a series of the samples with the higher $\mathrm{Al} / \mathrm{Mg}$ ratio $\left(\mathrm{Co}_{5} \mathrm{Mg}_{62} \mathrm{Al}_{33}\right.$ and $\left.\mathrm{Co}_{10} \mathrm{Mg}_{57} \mathrm{Al}_{33}\right)$, an increase in calcination temperature resulted in catalytic activation of the samples. Moreover, for the catalysts calcined at elevated temperatures higher selectivity to $\mathrm{CO}_{2}$ was achieved (apart from $\mathrm{CO}_{2}$ only $\mathrm{CO}$ was detected as a by-product).

For series of the catalysts with the lower $\mathrm{Al} / \mathrm{Mg}$ ratio $\left(\mathrm{Co}_{5} \mathrm{Mg}_{77} \mathrm{Al}_{18}\right.$ and $\left.\mathrm{Co}_{10} \mathrm{Mg}_{72} \mathrm{Al}_{18}\right)$, no simple correlation between their catalytic performance and calcination temperature was observed. In the $\mathrm{Co}_{5} \mathrm{Mg}_{77} \mathrm{Al}_{18}$ series, the sample calcined at $800{ }^{\circ} \mathrm{C}$ was significantly more active and selective to $\mathrm{CO}_{2}$ than the catalysts calcined at lower temperatures, which showed very similar catalytic activity in methanol incineration. The activity of the catalysts of $\mathrm{Co}_{10} \mathrm{Mg}_{72} \mathrm{Al}_{18}$ series was very similar and only slightly depended on the calcination temperature. Among the examined catalysts, the best results, with respect to activity and selectivity to $\mathrm{CO}_{2}$, were obtained for the $\mathrm{Co}_{10} \mathrm{Mg}_{57} \mathrm{Al}_{33}$ sample calcined at $800{ }^{\circ} \mathrm{C}$. Over the presence of the latter catalyst, methanol was completely oxidised to $\mathrm{CO}_{2}$ from $325^{\circ} \mathrm{C}$. This sample belongs to the group of very effective catalysts for methanol incineration (excluding noble metalbased catalysts) reported in the literature [27, 38, 39]. Such significant differences in the catalytic performance of the studied samples can be explained by various phase composition and redox properties of cobalt species present in these phases. As it was shown by UV-vis-DRS and XRD measurements, cobalt is present in the form of divalent and
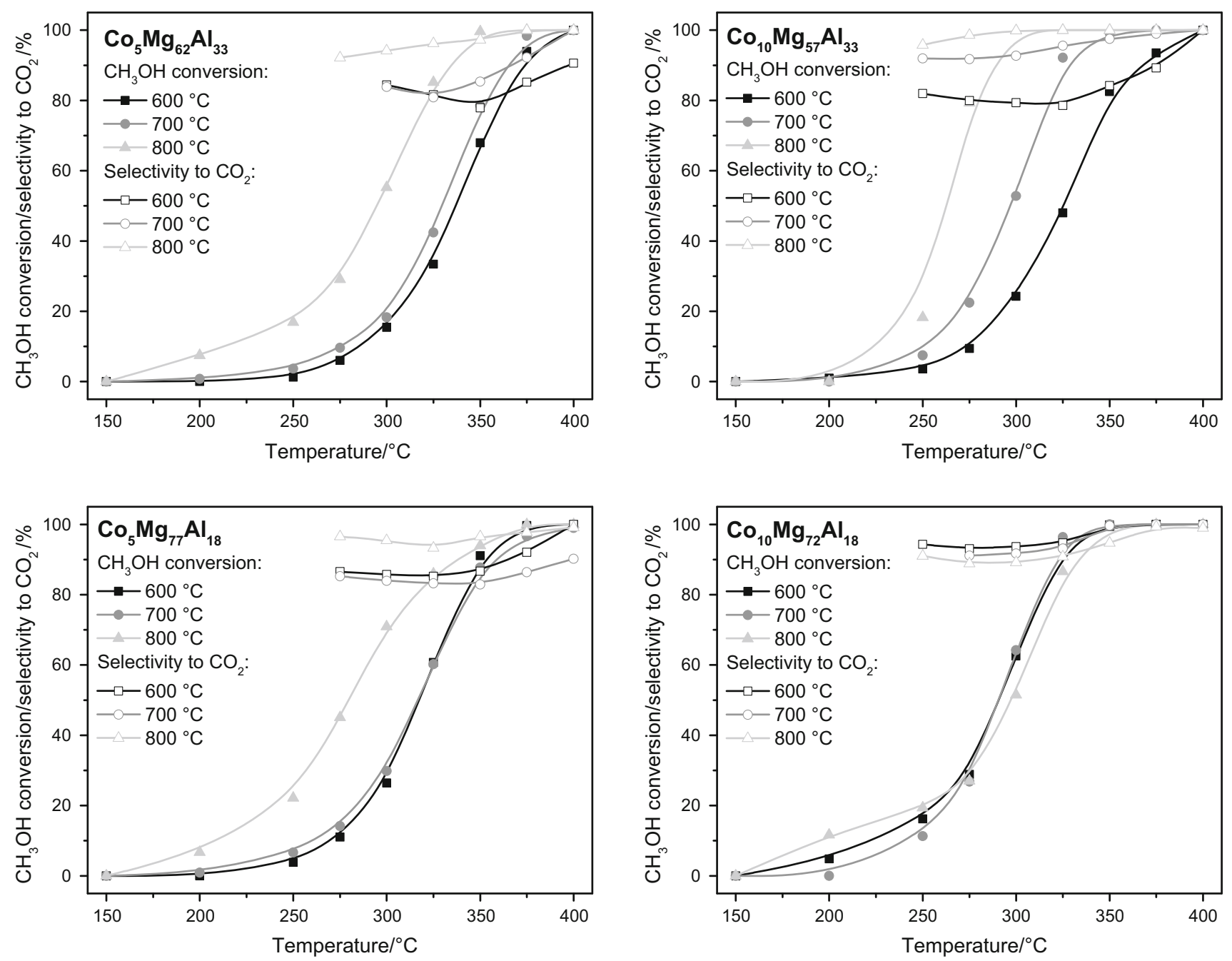

Fig. 8 Results of catalytic tests of the obtained mixed oxide catalysts in the methanol incineration 
trivalent cations in periclase-like and spinel-type mixed oxides (due to low content of cobalt and its high dispersion likely in the form of $\mathrm{Mg}_{1-\mathrm{x}} \mathrm{Co}_{\mathrm{x}} \mathrm{O}, \mathrm{Mg}_{(1-\mathrm{x})} \mathrm{Co}_{\mathrm{x}} \mathrm{Al}_{2} \mathrm{O}_{4}$ and $\left.\mathrm{MgCo}_{\mathrm{x}} \mathrm{Al}_{(2-\mathrm{x})} \mathrm{O}_{4}\right)$. Content of the spinel phases increased with increasing calcination temperature. The samples calcined at higher temperatures showed also better catalytic activity in the methanol incineration, especially in the case of the catalysts with the higher $\mathrm{Al} / \mathrm{Mg}$ ratio. Thus, it could be concluded that cobalt present in the spinel phases is catalytically more active in comparison with cobalt in periclase-like phase. It is well known that reduction of $\mathrm{Co}^{3+}$ to $\mathrm{Co}^{2+}$ in the spinel phases (e.g. $\mathrm{Co}_{3} \mathrm{O}_{4}$ or $\left.\mathrm{MgCo}_{\mathrm{x}} \mathrm{Al}_{(2-\mathrm{x})} \mathrm{O}_{4}\right)$ occurs at temperatures significantly lower in comparison to the reduction of $\mathrm{Co}^{2+}$ to $\mathrm{Co}^{0}$ in $\mathrm{CoAl}_{2} \mathrm{O}_{3}, \mathrm{Co}_{\mathrm{x}} \mathrm{Mg}_{(1-\mathrm{x})} \mathrm{Al}_{2} \mathrm{O}_{4}$ or $\mathrm{CoO}[36,37]$. Thus, cobalt oxide phases with spinel structure containing easily reducible $\mathrm{Co}^{3+}$ species $\left(\mathrm{Co}_{3} \mathrm{O}_{4}\right.$ or $\left.\mathrm{MgCo}_{\mathrm{x}} \mathrm{Al}_{(2-\mathrm{x})} \mathrm{O}_{4}\right)$ could be expected to be active components of the effective catalysts for methanol incineration. The cyclic voltammetry and $\mathrm{H}_{2}-$ TPR measurements showed the presence of easily reducible phase (Fig. 5, the reduction of $\mathrm{Co}^{3+}$ to $\mathrm{Co}^{2+}$ ) in the most active catalyst $\left(\mathrm{Co}_{10} \mathrm{Mg}_{57} \mathrm{Al}_{33}\right.$ sample calcined at $800{ }^{\circ} \mathrm{C}$ ). Moreover, this reduction process was intensified in the subsequent voltammetric cycles (Fig. 6). Such effects related to the presence of the easily reducible phase as well as intensification of the reduction process were not observed for other catalysts exhibiting lower catalytic activity. Therefore, it could be suggested that this easily reducible phases, formed during high-temperature treatment $\left(800{ }^{\circ} \mathrm{C}\right)$ of hydrotalcite-like precursor, are responsible for high catalytic activity in the process of methanol incineration. Taking into account the fact that the most active catalyst $\left(\mathrm{Co}_{10} \mathrm{Mg}_{57} \mathrm{Al}_{33}\right.$ sample calcined at $\left.800{ }^{\circ} \mathrm{C}\right)$ contained more than three times higher aluminium content and nearly six times higher amount of magnesium in comparison with cobalt content, the formation of the $\mathrm{MgCo}_{\mathrm{x}} \mathrm{Al}_{(2-\mathrm{x})} \mathrm{O}_{4}$ spinel phase is more favourable than formation of $\mathrm{Co}_{3} \mathrm{O}_{4}$. Moreover, the presence of $\mathrm{Co}_{3} \mathrm{O}_{4}$ was not confirmed by UV-vis-DR studies. Thus, it could be suggested that the $\mathrm{MgCo}_{\mathrm{x}} \mathrm{Al}_{(2-\mathrm{x})} \mathrm{O}_{4}$ spinel-type mixed oxide is more catalytically active in comparison with other cobalt-containing phases present in the $\mathrm{Co}_{10} \mathrm{Mg}_{57} \mathrm{Al}_{33}$ catalysts (e.g. $\mathrm{Mg}_{1-\mathrm{x}} \mathrm{Co}_{\mathrm{x}} \mathrm{O}$ periclase-like oxide) and is responsible for the enhanced catalytic activity of the sample calcined at high temperature $\left(800{ }^{\circ} \mathrm{C}\right)$.

\section{Conclusions}

The $\mathrm{Co}-\mathrm{Mg}-\mathrm{Al}$ mixed metal oxides were obtained from hydrotalcite-like precursors with various cobalt contents and different $\mathrm{Mg} / \mathrm{Al}$ ratios by calcination at 600,700 and $800{ }^{\circ} \mathrm{C}$. The prepared mixed oxides were tested as catalysts in methanol incineration. It was shown that both cation composition of hydrotalcite-like precursors and calcination temperature strongly influenced the catalytic performance of the mixed metal oxides. Among the studied samples, the best catalytic results were obtained with the $\mathrm{Co}_{10} \mathrm{Mg}_{57} \mathrm{Al}_{33}$ sample having high cobalt content and lower $\mathrm{Mg} / \mathrm{Al}$ ratio, calcined at $800{ }^{\circ} \mathrm{C}$. High catalytic activity of the latter was related to the presence of $\mathrm{Co}^{3+}$-containing spinel-type phase, very likely the $\mathrm{MgCo}_{\mathrm{x}} \mathrm{Al}_{(2-\mathrm{x})} \mathrm{O}_{4}$ mixed oxide; it was probably more catalytically active in methanol incineration than other cobalt-containing phases formed during calcination of the hydrotalcite-like precursor. High catalytic activity of the spinel phase was ascribed to the relatively easy reducibility of $\mathrm{Co}^{3+}$ to $\mathrm{Co}^{2+}$ cations identified by voltammetry and $\mathrm{H}_{2}$-TPR measurements.

Acknowledgements Part of the research was done with equipment purchased in the frame of European Regional Development Fund (Polish Innovation Economy Operational Program-Contract No. POIG.02.01.00-12-023/08).

Open Access This article is distributed under the terms of the Creative Commons Attribution 4.0 International License (http://creative commons.org/licenses/by/4.0/), which permits unrestricted use, distribution, and reproduction in any medium, provided you give appropriate credit to the original author(s) and the source, provide a link to the Creative Commons license, and indicate if changes were made.

\section{References}

1. Zhang Z, Jiang Z, Shangguan W. Low-temperature catalysis for VOCs removal in technology and application: a state-of-the-art review. Catal Today. 2016;264:270-8.

2. Chiang YC, Chiang PC, Huang CP. Effects of pore structure and temperature on VOC adsorption on activated carbon. Carbon. 2001;39:523-34.

3. Toof LJ. A model for the prediction of thermal, prompt, and fuel $\mathrm{NO}_{\mathrm{x}}$ emissions from combustion turbines. Eng Gas Turbines Power. 1986;108:340-7.

4. Morales-Torres S, Maldonado-Hódar FJ, Pérez-Cadenas AF, Carrasco-Marín F. Design of low-temperature Pt-carbon combustion catalysts for VOC's treatments. J Hazard Mater. 2010;183:814-22.

5. Abdelouahab-Reddam Z, Mail ER, Coloma F, SepúlvedaEscribano A. Platinum supported on highly-dispersed ceria on activated carbon for the total oxidation of VOCs. Appl Catal A Gen. 2015;494:87-94.

6. Usón L, Colmenares MG, Hueso JL, Sebastián V, Balas F, Arruebo M, Santamaría J. VOCs abatement using thick eggshell Pt/SBA-15 pellets with hierarchical porosity. Catal Today. 2014;227:179-86.

7. Mitu M, Razus D, Oancea D. Effect of $\mathrm{CO}_{2}$ dilution on propaneair isothermal catalytic combustion on Platinum. J Therm Anal Calorim. 2017. doi:10.1007/s10973-017-6167-x.

8. Kim SC, Shim WG. Properties and performance of Pd based catalysts for catalytic oxidation of volatile organic compounds. Appl Catal B Environ. 2009;92:429-36.

9. Jabłońska M, Król A, Kukulska-Zając E, Tarach K, Girman V, Chmielarz L, Góra-Marek K. Zeolites Y modified with palladium as effective catalysts for low-temperature methanol incineration. Appl Catal B Environ. 2015;166-167:353-65. 
10. Huang H, Ye X, Huang H, Zhang L, Leung DYC. Mechanistic study on formaldehyde removal over $\mathrm{Pd} / \mathrm{TiO}_{2}$ catalysts: oxygen transfer and role of water vapor. Chem Eng J. 2013;230:73-9.

11. Kucherov AV, Sinev IM, Ojala S, Keiski R, Kustov LM. Adsorptive-catalytic removal of $\mathrm{CH}_{3} \mathrm{OH}, \mathrm{CH}_{3} \mathrm{SH}$, and $\mathrm{CH}_{3}$ $\mathrm{SSCH}_{3}$ from air over the bifunctional system noble metals/ HZSM-5. Stud Surf Sci Catal. 2007;170:1129-36.

12. Chen BB, Zhu XB, Crocker M, Wang Y, Shi C. $\mathrm{FeO}_{\mathrm{x}}$-supported gold catalysts for catalytic removal of formaldehyde at room temperature. Appl Catal B: Environ. 2014;154-155:73-81.

13. Delannoy L, Fajerwerg K, Lakshmanan P, Potvin C, Méthivier C, Louis C. Supported gold catalysts for the decomposition of VOC: total oxidation of propene in low concentration as model reaction. Appl Catal B: Environ. 2010;94:117-24.

14. Solsona B, Davies TE, Garcia T, Vazquez I, Dejoz A, Taylor SH. Total oxidation of propane using nanocrystalline cobalt oxide and supported cobalt oxide catalysts. Appl Catal B: Environ. 2008;84: 176-84.

15. Jirátová K, Mikulová J, Klempa J, Grygar T, Bastl Z, Kovanda F. Modification of $\mathrm{Co}-\mathrm{Mn}-\mathrm{Al}$ mixed oxide with potassium and its effect on deep oxidation of VOC. Appl Catal A Gen. 2009;361: 106-16.

16. Basąg S, Piwowarska Z, Kowalczyk A, Węgrzyn A, Baran R, Gil B, Michalik M, Chmielarz L. Cu-Mg-Al hydrotalcite-like materials as precursors of effective catalysts for selective oxidation of ammonia to dinitrogen - the influence of $\mathrm{Mg} / \mathrm{Al}$ ratio and calcination temperature. Appl Clay Sci. 2016;129:122-30.

17. Jabłońska M, Chmielarz L, Wegrzyn A, Guzik K, Piwowarska Z, Witkowski S, Walton RI, Dunne PW, Kovanda F. Thermal transformations of $\mathrm{Cu}-\mathrm{Mg}(\mathrm{Zn})-\mathrm{Al}(\mathrm{Fe})$ hydrotalcite-like materials into metal oxide systems and their catalytic activity in selective oxidation of ammonia to dinitrogen. J Therm Anal Calorim. 2013;114:731-47.

18. Chmielarz L, Rutkowska M, Kuśtrowski P, Drozdek M, Piwowarska Z, Dudek B, Dziembaj R, Michalik M. An influence of thermal treatment conditions of hydrotalcite-like materials on their catalytic activity in the process of $\mathrm{N}_{2} \mathrm{O}$ decomposition. J Therm Anal Calorim. 2011;105(161):70.

19. Kuśtrowski P, Wȩgrzyn A, Chmielarz L, Bronkowska A, Rafalska-Łasocha A, Dziembaj R. Thermally induced transformations in polyoxometalate-pillared hydrotalcites. J Therm Anal Calorim. 2004;77(243):51.

20. Bankauskaite A, Baltakys K. Thermal, texture and reconstruction properties of hydrotalcites substituted with $\mathrm{Na}^{+}$or $\mathrm{K}^{+}$ions. J Therm Anal Calorim. 2015;121(227):33.

21. Smolakova L, Frolich K, Troppova I, Kutalek P, Kroft E, Capek L. Determination of basic sites in $\mathrm{Mg}-\mathrm{Al}$ mixed oxides by combination of TPD- $\mathrm{CO}_{2}$ and $\mathrm{CO}_{2}$ adsorption calorimetry. When the same basic sites are reported from both techniques? J Therm Anal Calorim. 2017;127:1921-9.

22. Meloni D, Monaci R, Cutrufello MG, Rombi E, Ferino I. Adsorption microcalorimetry characterization of K-doped $\mathrm{MgAl}$ mixed oxide catalysts for soybean oil transesterification synthesized by impregnation and ball milling techniques. J Therm Anal Calorim. 2015;119:1023-36.

23. Coriolano ACF, Alves AA, Araujo RA, Delgado RCOB, Carvalho FR, Fernandes VJ Jr, Araujo AS. Thermogravimetry study of the ester interchange of sunflower oil using $\mathrm{Mg} / \mathrm{Al}$ layered double hydroxides (LDH) impregnated with potassium. J Therm Anal Calorim. 2017;127:1863-7.
24. Cavani F, Trifiro F, Vaccari A. Hydrotalcite-type anionic clays: preparation, properties and applications. Catal Today. 1991;11: 173-301.

25. Taguchi M, Nakane T, Hashi K, Ohki S, Shimizu T, Sakka Y, Matsushita A, Abe H, Funazukuri T, Naka T. Reaction temperature variations on the crystallographic state of spinel cobalt aluminate. Dalton Trans. 2013;42:7167-76.

26. Li Y, Lu G, Ma J. Highly active and stable nano NiO-MgO catalyst encapsulated by silica with a core-shell structure for $\mathrm{CO}_{2}$ methanation. RSC Adv. 2014;4:17420-8.

27. Jabłońska M, Chmielarz L, Węgrzyn A, Góra-Marek K, Piwowarska Z, Witkowski S, Bidzińska E, Kuśtrowski P, Wach A, Majda D. Hydrotalcite derived ( $\mathrm{Cu}, \mathrm{Mn})-\mathrm{Mg}-\mathrm{Al}$ metal oxide systems doped with palladium as catalysts for low-temperature methanol incineration. App Clay Sci. 2015;114:273-82.

28. Kovanda F, Rojka T, Bezdička P, Jirátová K, Obalová L, Pacultová K, Bastl Z, Grygar T. Effect of hydrothermal treatment on properties of $\mathrm{Ni}-\mathrm{Al}$ layered double hydroxides and related mixed oxides. J Solid State Chem. 2009;182:27-36.

29. Zhang Q, Chen C, Wang M, Cai J, Xu J, Xia C. Facile preparation of highly-dispersed cobalt-silicon mixed oxide nanosphere and its catalytic application in cyclohexane selective oxidation. Nanoscale Res Lett. 2011;6:1-7.

30. Morpurgo S, Lojacono M, Porta P. Pillared hydroxycarbonates and mixed oxides. Part 1. Copper-zinc-cobalt-aluminum system. J Mater Chem. 1994;4:197-204.

31. Zayat M, Levy D. Blue $\mathrm{CoAl}_{2} \mathrm{O}_{4}$ particles prepared by the sol-gel and citrate-gel methods. Chem Mater. 2000;12:2763-9.

32. Liotta LF, Pantaleo G, Macaluso A, Di Carlo D, Deganello G. $\mathrm{CoO}_{\mathrm{x}}$ catalysts supported on alumina and alumina-baria: influence of the support on the cobalt species and their activity in $\mathrm{NO}$ reduction by $\mathrm{C}_{3} \mathrm{H}_{6}$ in lean conditions. Appl Catal A Gen. 2003;245:167-77.

33. van de Water LGA, Leendert Bezemer G, Versluijs-Helder JABM, Weckhuysen BM, de Jong KP. Spatially resolved UV-vis microspectroscopy on the preparation of alumina-supported Co Fischer-Tropsch catalysts: linking activity to Co distribution and speciation. J Catal. 2006;242:287-98.

34. Vakros J, Kordulis C, Lycourghiotis A. Cobalt oxide supported $\gamma$ alumina catalyst with very high active surface area prepared by equilibrium deposition filtration. Langmuir. 2002;18:417-22.

35. Krezhov $\mathrm{K}$, Konstantinov $\mathrm{P}$. On the cationic distribution in $\mathrm{Mg}_{\mathrm{x}} \mathrm{Co}_{3-\mathrm{x}} \mathrm{O}_{4}$ spinels. J Phys Condens Mater. 1992;4:L543-8.

36. Han J, Jia L, Hou B, Li D, Liu Y, Liu Y. Catalytic properties of $\mathrm{CoAl}_{2} \mathrm{O}_{4} / \mathrm{Al}_{2} \mathrm{O}_{3}$ supported cobalt catalysts for Fischer-Tropsch synthesis. J Fuel Chem Technol. 2015;43:846-51.

37. Yu C, Zhou X, Weng W, Hu J, Chen X, Wei L. Effects of alkaline-earth strontium on the performance of $\mathrm{Co} / \mathrm{Al}_{2} \mathrm{O}_{3}$ catalyst for methane partial oxidation. J Fuel Chem Technol. 2012;40: 1222-9.

38. Chmielarz L, Piwowarska Z, Rutkowska M, Wojciechowska M, Dudek B, Witkowski S, Michalik M. Total oxidation of selected mono-carbon VOCs over hydrotalcite originated metal oxide catalysts. Catal Commun. 2012;17:118-25.

39. Dziembaj R, Molenda M, Chmielarz L, Zaitz MM, Piwowarska $\mathrm{Z}$, Rafalska-Łasocha A. Optimization of $\mathrm{Cu}$ doped ceria nanoparticles as catalysts for low-temperature methanol and ethylene total oxidation. Catal Today. 2011;69:112-7. 